\title{
Risk Factors for Anemia Among Pregnant Women
} Attending the Antenatal Care Unit in Selected Jigjiga Public Health Facilities, Somali Region, East Ethiopia 2019: Unmatched Case-Control Study

This article was published in the following Dove Press journal:

Journal of Multidisciplinary Healthcare

\author{
Mohamed Omar Osman (1D \\ Tahir Yousuf Nour (D) \\ Hodan Mahamed Bashir ${ }^{2}$ \\ Abdurahman Kedir Roble (iD ${ }^{3}$ \\ Abdikani Mawlid Nur' \\ Abdilahi Omer Abdilahi ${ }^{\prime}$ \\ 'Department of Public Health, College of \\ Medicine and Health Science, Jigjiga \\ University, Jigiiga, Ethiopia; ${ }^{2}$ Department \\ of Food Science and Nutrition, College of \\ Dryland Agriculture, Jigjiga University, \\ Jigjiga, Ethiopia; ${ }^{3}$ Department of \\ Midwifery, College of Medicine and \\ Health Science, Jigjiga University, Jigjiga, \\ Ethiopia
}

Background: Anemia is a significant public health concern in many developing countries, particularly during pregnancy, and it has adverse effects on mother and fetus/baby.

Objective: To determine the factors associated with anemia among pregnant women attending antenatal care in Jigjiga public health facilities, Somali Region, East Ethiopia.

Methods: An institution-based unmatched case-control study was conducted. The sample size was 228 pregnant women; comprising 114 presenting with anemia and 114 controls. Hemoglobin levels were measured using a portable heme analyzer. Socio-demographic, dietary, medical history, and nutrition-related data were collected using a structured questionnaire. Data were entered into Epidata 3.1 and exported to Statistical Package for the Social Sciences (SPSS) version 23.0 for cleaning and analyses. Bivariate and multivariate logistic regression was performed and statistical significance was considered at a level of $\mathrm{p}<0.05$.

Results: Three predictors of anemia among pregnant women were identified in this study. An inadequate intake of red meat (i.e. those who consumed red meat 1-2 times a month $[\mathrm{AOR}=7.245 ; 95 \% \mathrm{CI}=(2.007-26.151)]$ or not at all $[\mathrm{AOR}=8.690 ; 95 \% \mathrm{CI}=(1.795-42.072)])$, and insufficient consumption of green vegetables (i.e. $1-2$ times a week $[\mathrm{AOR}=2.970 ; 95 \% \mathrm{CI}=$ $(1.012-8.716)]$ or $1-2$ times a month $[\mathrm{AOR}=8.057 ; 95 \% \mathrm{CI}=(2.358-27.526)])$ were associated with anemia. Also, having a mid-upper arm circumference (MUAC) of less than $23 \mathrm{~cm}$ was strongly associated $[\mathrm{AOR}=16.432 ; 95 \% \mathrm{CI}=(5.240-51.526)]$ with anemia

Conclusion: This study revealed three key factors to be associated with anemia among pregnant women in Jigjiga Town, namely reduced intake of red meat and green vegetables, and low MUAC. Interventions including nutrition counselling and enrolling pregnant women with low nutritional status in nutritional programs should be the core components of anemia control strategies, needed to address the high prevalence of anemia during pregnancy in developing countries.

Keywords: risk factors, anemia, pregnant women, antenatal care, Jigjiga Town

\section{Introduction}

Anemia is a global public health problem affecting people of all ages in both developing and developed countries. Anemia is a condition in which the number and size of red blood cells, or the hemoglobin $(\mathrm{Hb})$ concentration, falls below an established cut-off value, consequently reducing the ability of the blood to transport oxygen around the body. ${ }^{1}$ According to the World Health Organization (WHO), anemia in pregnancy is defined as a $\mathrm{Hb}$ concentration of less than 11 grams per
Correspondence: Mohamed Omar

Osman

P.O.BOX: 1020, Jigjiga, Ethiopia

Tel +251921424748

Fax +25I 257755976

Email Wehliye@jju.edu.et
Journal of Multidisciplinary Healthcare 2020:13 769-777

769 
deciliter $(\mathrm{g} / \mathrm{dl}){ }^{2}$ Anemia during pregnancy is a major cause of morbidity and mortality of pregnant women in developing countries, and has both maternal and fetal consequences. $^{3}$

Anemia has a number of causes, with the most significant contributor being iron deficiency. Reports state that approximately $50 \%$ of anemia cases are considered to be due to iron deficiency, but this varies by population group and region. ${ }^{4}$ Anemia in pregnant women has severe consequences on health, social, and economic development, resulting in increased risk of low physical activity, maternal morbidity, and mortality, especially in those with severe anemia. ${ }^{5}$

Anemia is preventable, controllable, and treatable, with effective management including treatment of the underlying causes, supplements to return the hemoglobin concentration to consistent levels, and preventing and treating any complications. ${ }^{5}$

The WHO estimates $40 \%$ of pregnant women worldwide are anemic, with iron deficiency anemia being the most common form. ${ }^{6}$ Annually, nearly 510,000 maternal deaths occur worldwide, associated with childbirth or early postpartum complications. Approximately 20\% of maternal death is caused by anemia; the majority of this taking place in developing countries. ${ }^{7}$ Gestational anemia has a significant global burden, affecting 32.4 million (38.2\%) of pregnant women. It is a severe public health problem in South East Asia (48.7\%) and Africa (46.3\%). ${ }^{4}$ Global data show that $56 \%$ of pregnant women in low- and middle-income countries (LMIC) have anemia. ${ }^{8}$ The Ethiopian demographic health survey (EDHS, 2016) revealed that the incidence of anemia among pregnant women represented $29 \%$ of those with the condition at a national level, and that specifically, the prevalence was $60 \%$ in pregnant women of the Somali region, East Ethiopia.' ${ }^{9}$ Further, studies conducted in Ethiopia have shown that the type of residence, gravidity, interval between pregnancies, and malaria infection during pregnancy have been associate with gestational anemia. ${ }^{10}$

Severe anemia $(<7 \mathrm{~g} / \mathrm{L})$ during pregnancy has been associated with major maternal and fetal complications. It increases the risk of preterm delivery, low birth weight, intrauterine fetal death, neonatal death, maternal mortality, and consequently infant mortality. ${ }^{11}$

Anemia has multifactorial etiology and risk factors; particularly in developing countries, with substantial differences in known risk factors within and between the regions of the same country. Research findings have revealed that determinants of anemia vary from place to place. This highlights the importance of determining the problem-based factors associated with anemia using a strong study design in order to obtain local data in atrisk regions, specifically in the developing world. Therefore, this study was carried out with the objective of determining the risk factors associated with anemia among pregnant women attending antenatal care services in selected Jigjiga public health facilities in the Somali region of East Ethiopia in 2019.

\section{Materials and Methods} Study Design and Setting

A facility-based unmatched case-control study design was used. The study was conducted in Sheik Hassan Yabare Referral Hospital and Ayardaga Health Center, Jigjiga, East Ethiopia. Jigjiga is a city situated $626 \mathrm{~km}$ east from Addis Ababa, the capital city of Ethiopia. As of the 2015 Ethiopian fiscal year, Jigjiga had a total population of 426,122, of which 85,650 are considered to be in the reproductive age group (15-49 years). The city is divided into 30 sub-districts (the smallest administration units), of which 20 are urban and 10 are rural. The vast majority of the population are ethnic Somalis (97\%), and Muslim (98\%). ${ }^{12}$ This study was conducted between March 1 and April 30, 2019.

\section{Sample Size Determination and Sampling Technique}

The sample size was calculated using Epi Info version 7.2 assuming a $95 \%$ confidence interval (CI) and power of 80 , with a case to control ratio of $1: 1$. The effect size used was an odds ratio for factors associated with anemia of 2.34 from a recent study conducted in Durame, Ethiopia. ${ }^{13}$ The resulting maximum sample size was 114 cases and 114 controls with a total of 228 study participants. Jigjiga has four public health facilities that provide antenatal care services to pregnant mothers. Of these, two facilities were selected by simple random sampling. The number of study subjects was allocated to each selected facility proportionally to their average patient attendance permonth by reviewing registration books from each antenatal care unit. The average number of pregnant women who attended antenatal care per month was multiplied by the total sample size $(n=228)$ divided by the total number of pregnant women attending across all antenatal care facilities per month (460). Systematic random sampling was 
used to select study participants on this basis, such that 114 anemia cases and 114 controls were identified.

\section{Ethical Approval}

Ethical approval was obtained from the Institutional Review Board (IRB) of Jigjiga University, College of Medicine and Health Science in accordance with the Declaration of Helsinki. Written permission was obtained from Jigjiga administrative health department, and from each selected facility. Participants were informed that participation was on a voluntary basis. Informed, written consent was obtained from each study participant. In participants aged under 18 years, written assent was obtained from someone with parental responsibility. All study data were anonymized at source. Anemic cases were provided with free iron-folic acid supplements and counseled to prepare and increase their dietary iron intake.

\section{Inclusion and Exclusion Criteria}

Pregnant women who attended antenatal care for their first visit, and were measured to have a hemoglobin level less than $11 \mathrm{~g} / \mathrm{dl}$ were recruited into the anemia group. Pregnant women who attend antenatal care for their first visit and presented with hemoglobin levels greater than 11 $\mathrm{g} / \mathrm{dl}$ were recruited into the control group. Any attendee who was ill with confirmed acute and/or chronic diseasecausing anemia, and/or who was undergoing invasive or non-invasive anemia treatment (regardless of their hemoglobin level) was excluded from the study.

\section{Data Collection Techniques and Tools}

A validated questionnaire was designed to obtain participant information on socio-demographic factors, obstetrics characteristics, nutrition-related characteristics, and parasitic infection-related characteristics. The Dietary Diversity Questionnaire (DDQ) was used to assess the typical dietary intake of pregnant women over the past six months. This comprised a detailed review of their typical intake of various food groups, and the quantity per day, week, or month. The questionnaire was initially developed in English and translated to the local language (Somali) before being translated back to English. Data were collected by interview by four midwives, and specimen collection and processing were carried out by two trained laboratory technologists. Specimen collection, processing, and analysis were supervised by skilled and trained laboratory technicians and trained health professionals with research experience. All data collectors and supervisors were trained for two days on the data collection process and questionnaire.

\section{Blood Sample Collection and Examination}

Hemoglobin levels were measured using a portable heme Analyzer (HemoCue $301 \mathrm{Hb}$; HemoCue, Ängelholm, Sweden). The middle finger of the non-dominant hand was pricked at the side of the fingertip. A drop of blood was drawn, and placed onto a micro-cuvette, which was then inserted into the heme Analyzer. After calibration of the machine, hemoglobin levels were read and recorded to one decimal place. The packed cell volume was estimated by tripling the hemoglobin values (in $\mathrm{g} / \mathrm{dl}$ ) and dropping the units. Anthropometric measurements (MUAC; midupper arm circumference) were measured using a tape measure. A MUAC of less than $23 \mathrm{~cm}$ was considered to signify malnutrition. ${ }^{14}$

\section{Data Quality Control}

To ensure data quality, an appropriate data collection instrument was developed. Data collectors were regularly supervised for proper data collection; all the questionnaires were checked for completeness and consistency on a daily basis. A pretest pilot study was conducted on $5 \%$ of the sample size in a single nearby public hospital (Karamara hospital; not one of the recruitment sites for the main study), following which the questionnaire was revised and edited, and any questions found to be unclear or ambiguous were removed or corrected accordingly.

\section{Data Processing and Analysis}

Data were entered into Epidata version 3.1 and analyzed using Statistical Package for Social Sciences (SPSS) version 20.0. Descriptive statistics were used to inspect frequencies and percentages. Bivariate and multivariate logistic regression analyses were used to test for the association between dependent and independent variables. Variables that showed an association in the bivariate analysis with $\mathrm{p}<0.25$ were entered into a multivariate logistic regression model. Finally, the multivariate logistic regression model was used after controlling for confounding factors using regression. ${ }^{15,16}$ Hosmer and Lemeshow's goodness of fit test was used to assess whether the necessary assumptions for the application of multivariate logistic regression had been fulfilled. Multi-collinearity was assessed by using standard error, and the variables were entered into the multivariate model without multicollinearity. Adjusted odds ratios (AOR) were calculated 
with 95\% CIs. Statistical significance was reported at a threshold of $\mathrm{p}<0.05$.

\section{Results}

\section{Socioeconomic Characteristics}

All 228 participants (114 with anemia and 114 controls) completed all components of the study. The majority (97.4\%) of the anemia group and $100 \%$ of the control group were from urban areas, while only $2.7 \%$ of the anemia group were from rural areas. The mean ( \pm standard deviation) age of participants was $24.96 \pm 5$. Twenty-two years, and the range from 16 to 38 years. Ninety-seven participants in the anemia group (85.1\%) and 78 (68.4\%) controls had some kind of informal education. The occupational status of the majority of participants was home-maker (anemia group 103; $90.4 \%$ and control group $109 ; 95 \%$ ). All study participants in both groups were married. Thirty-five (30.7\%) of the anemia group and $29(25.4 \%)$ controls reported a family size greater than 5 . The majority of study participants in both groups were Muslim, while only $2(1.8 \%)$ of the anemia group were Orthodox Christians. One hundred and four (91.2\%) participants in the anemia group and 75 (68.5\%) controls had a monthly income of between 500-5000 Birr (approximately \$14 - 140 USD; Table 1).

\section{Food Intake}

In the analysis of the food and nutrition intake of study participants, $8(7.0 \%)$ members of the anemic group and 29 (25.4\%) controls consumed red meat every day. Eighty-three (72.8\%) anemic participants and 61 (53.5\%) controls never ate fish, and 113 (98.2\%) of anemic group and 98 (86\%) the controls did not consume white meat at all. Sixteen (14.0\%) of those with anemia and $47(41.2 \%)$ controls consumed green vegetables every day. One hundred and five (92.1\%) members of the anemic group and 97 (85.1\%) controls never consumed nuts, while $112(98.2 \%)$ of the anemic group and $113(99.1 \%)$ controls consumed grains daily. Forty-two (36.8\%) of the case group and 37 (32.5\%) controls never consumed pulses (lentils and beans).

Regarding tea and coffee consumption, 96 (84.2\%) of the anemic group and $77(67.5 \%)$ of the controls used everyday tea while $99(86.8 \%)$ of the cases and 103 (90.4\%) of the controls never drink coffee (Table 2).

\section{Obstetric and Disease Factors}

The majority of participants in both groups (anemic: 86 ; $75.4 \%$; controls: $85 ; 74.6 \%$ ) were multigravida women,
Table I Socio-Demographic Characteristics of Pregnant Mothers Attending ANC in Selected Jigjiga Public Health Facilities, 2019

\begin{tabular}{|c|c|c|c|c|}
\hline $\begin{array}{l}\mathbf{S} / \\
\mathbf{N}\end{array}$ & Variables & Category & $\begin{array}{l}\text { Case } \\
(n=114) \\
\text { Frequency } \\
\text { (\%) }\end{array}$ & $\begin{array}{l}\text { Control } \\
(n=1 \mid 4) \\
\text { Frequency } \\
(\%)\end{array}$ \\
\hline 1 & Residence & $\begin{array}{l}\text { Rural } \\
\text { Urban }\end{array}$ & $\begin{array}{l}3(2.6) \\
\text { III (97.4) }\end{array}$ & $\begin{array}{l}0(0) \\
114(100)\end{array}$ \\
\hline 2 & Age & $\begin{array}{l}14-24 \\
25-34 \\
35-49\end{array}$ & $\begin{array}{l}52(45.6) \\
56(49.1) \\
6(5.3)\end{array}$ & $\begin{array}{l}53(46.5) \\
56(49.1) \\
5(4.4)\end{array}$ \\
\hline 3 & Educational status & $\begin{array}{l}\text { Informal } \\
\text { education } \\
\text { Formal } \\
\text { education }\end{array}$ & $\begin{array}{l}97(85.1) \\
17(15.0)\end{array}$ & $\begin{array}{l}71(62.3) \\
43(37.7)\end{array}$ \\
\hline 4 & Occupation status & $\begin{array}{l}\text { Employed } \\
\text { Housewife }\end{array}$ & $\begin{array}{l}7(6.1) \\
107(93.9)\end{array}$ & $\begin{array}{l}8(7.0) \\
106(93.0)\end{array}$ \\
\hline 6 & $\begin{array}{l}\text { Monthly income } \\
\text { (in Birr) (ETB/USD } \\
=0.029)\end{array}$ & $\begin{array}{l}500-5000 \\
500-1000\end{array}$ & $\begin{array}{l}104(91.2) \\
10(8.8)\end{array}$ & $\begin{array}{l}75(65.8) \\
39(34.2)\end{array}$ \\
\hline 7 & Family size & $\begin{array}{l}<5 \\
>5\end{array}$ & $\begin{array}{l}79(69.3) \\
35(30.7)\end{array}$ & $\begin{array}{l}85(74.6) \\
29(25.4)\end{array}$ \\
\hline 8 & Religious belief & Muslim & $112(98.2)$ & $114(100)$ \\
\hline
\end{tabular}

i.e. those for whom this was not their first pregnancy. Those who attended further follow-up antenatal care during the same pregnancy were $87(76.3 \%)$ of the anemic women and 103 (90.4\%) of the controls. Fifty-four $(47.4 \%)$ of both groups of women were in their second trimester of pregnancy. Three (2.6\%) and $12(10.5 \%)$ of the anemic group had experienced diarrhea and fever, respectively, in the previous two weeks, compared to the control group where $2(1.8 \%)$ and $2(1.8 \%)$ had suffered fever in the past two weeks (Table 3).

\section{Anthropometric Characteristics}

The majority of the study participants were considered malnourished, with a MUAC of less than $23 \mathrm{~cm} ; 108$ $(94.7 \%)$ in the anemic group and $79(62.3 \%)$ of the control group (Table 4).

\section{Predictors of Anemia}

The results of multivariate logistic regression analysis showed that red meat consumption, green vegetable consumption, and MUAC were considered to be significantly associated with anemia in pregnant women. Pregnant mothers who consumed red meat 1-2 times a month 
Table 2 Animal and Plant Source Food Frequency Questionnaire of Pregnancy Mother Attending ANC in Selected Jigjiga Public Health Facilities, 2019

\begin{tabular}{|c|c|c|c|c|}
\hline $\mathbf{S} / \mathbf{N}$ & Variables & Categorical & Case $(n=1 \mid 4)$ Frequency $(\%)$ & Control $(n=114)$ Frequency (\%) \\
\hline 1 & Red meat & $\begin{array}{l}\text { Everyday } \\
3-5 \text { times a week } \\
\text { I-2 times a week } \\
\text { I-2 times month } \\
\text { Do not take }\end{array}$ & $\begin{array}{l}8(7.0) \\
11(9.6) \\
25(21.9) \\
37(32.5) \\
33(28.9)\end{array}$ & $\begin{array}{l}29(25.4) \\
32(28.1) \\
35(30.7) \\
14(12.3) \\
4(3.5)\end{array}$ \\
\hline 2 & Fish (fresh fish, packed fish) & $\begin{array}{l}\text { Everyday } \\
3-5 \text { times a week } \\
\text { I-2 times a week } \\
\text { I-2 times a month } \\
\text { Do not take }\end{array}$ & $\begin{array}{l}\text { I }(0.9) \\
4(3.5) \\
2(1.8) \\
24(21.1) \\
83(72.8)\end{array}$ & $\begin{array}{l}\text { I }(0.9) \\
3(2.6) \\
21(18.4) \\
28(24.6) \\
61(53.5)\end{array}$ \\
\hline 3 & White meat (chicken and turkey) & $\begin{array}{l}\text { I-2 times a week } \\
\text { I-2 times a month } \\
\text { Do not take }\end{array}$ & $\begin{array}{l}0(0) \\
0(0) \\
113(98.2)\end{array}$ & $\begin{array}{l}2(1.8) \\
8(7) \\
98(86)\end{array}$ \\
\hline 4 & Green vegetables & $\begin{array}{l}\text { Everyday } \\
3-5 \text { times a week } \\
\text { I-2 times a week } \\
\text { I-2 times a month } \\
\text { Do not take }\end{array}$ & $\begin{array}{l}16(14.0) \\
15(13.2) \\
22(19.3) \\
39(34.2) \\
22(19.3)\end{array}$ & $\begin{array}{l}47(41.2) \\
36(31.6) \\
14(12.3) \\
10(8.8) \\
7(6.1)\end{array}$ \\
\hline 5 & Nut & $\begin{array}{l}3-5 \text { times a week } \\
\text { I-2 times a week } \\
\text { I-2 times a month } \\
\text { Do not take }\end{array}$ & $\begin{array}{l}4(3.5) \\
3(2.6) \\
2(1.8) \\
105(92.1)\end{array}$ & $\begin{array}{l}5(4.4) \\
7(6.1) \\
5(4.4) \\
97(85.1)\end{array}$ \\
\hline 6 & Pulses (lentils and beans) & $\begin{array}{l}\text { Everyday } \\
3-5 \text { times a week } \\
\text { I-2 times a week } \\
\text { I-2 times a month } \\
\text { Do not take }\end{array}$ & $\begin{array}{l}2(1.8) \\
4(3.5) \\
7(6.1) \\
59(51.8) \\
42(36.8)\end{array}$ & $\begin{array}{l}5(4.4) \\
6(5.3) \\
16(14) \\
50(43.9) \\
37(32.5)\end{array}$ \\
\hline 7 & Grains & $\begin{array}{l}\text { Everyday } \\
3-5 \text { times a week }\end{array}$ & $\begin{array}{l}112(98.2) \\
2(1.8)\end{array}$ & $\begin{array}{l}\text { I I } 3(99.1) \\
\text { I }(0.9)\end{array}$ \\
\hline 8 & Dried fruits & $\begin{array}{l}\text { Everyday } \\
3-5 \text { times a week } \\
\text { I-2 times a week } \\
\text { I-2 times a month } \\
\text { Do not take }\end{array}$ & $\begin{array}{l}0(0) \\
10(8.8) \\
14(12.3) \\
54(47.4) \\
36(31.6)\end{array}$ & $\begin{array}{l}5(4.4) \\
22(19.3) \\
35(30.7) \\
39(34.2) \\
13(11.4)\end{array}$ \\
\hline 9 & Tea & $\begin{array}{l}\text { Everyday } \\
3-5 \text { times a week } \\
\text { I-2 times a week } \\
\text { I-2 times a month } \\
\text { Do not take }\end{array}$ & $\begin{array}{l}96(84.2) \\
6(5.3) \\
2(1.8) \\
5(4.4) \\
5(4.4)\end{array}$ & $\begin{array}{l}77(67.5) \\
16(14.0) \\
12(10.5) \\
2(1.8) \\
7(6.1)\end{array}$ \\
\hline 10 & Coffee & $\begin{array}{l}\text { Everyday } \\
3-5 \text { times a week } \\
\text { I-2 times a week } \\
\text { I-2 times a month }\end{array}$ & $\begin{array}{l}4(3.5) \\
3(2.6) \\
2(1.8) \\
6(5.3)\end{array}$ & $\begin{array}{l}1(0.9) \\
4(3.5) \\
4(3.5) \\
2(2.6)\end{array}$ \\
\hline
\end{tabular}


Table 3 Health Conditions During the Current Pregnancy Mother Attending ANC in Selected Jigjiga Public Health Facilities, 2019

\begin{tabular}{|c|c|c|c|c|}
\hline $\begin{array}{l}\mathbf{N} / \\
\mathbf{S}\end{array}$ & Variables & Categorical & $\begin{array}{l}\text { Case }(n=114) \text { Frequency } \\
(\%)\end{array}$ & $\begin{array}{l}\text { Control }(n=114) \text { Frequency } \\
(\%)\end{array}$ \\
\hline 1 & Gravidity & $\begin{array}{l}\text { Primigravidae } \\
\text { Multigravida }\end{array}$ & $\begin{array}{l}28(24.6) \\
86(75.4)\end{array}$ & $\begin{array}{l}29(25.4) \\
85(74.6)\end{array}$ \\
\hline 2 & ANC follow current pregnancy & $\begin{array}{l}\text { Yes } \\
\text { No }\end{array}$ & $\begin{array}{l}87(76.3) \\
27(23.7)\end{array}$ & $\begin{array}{l}103(90.4) \\
11(9.6)\end{array}$ \\
\hline 3 & Gestational age & $\begin{array}{l}\text { Ist trimester } \\
\text { 2nd trimester } \\
\text { 3rd trimester }\end{array}$ & $\begin{array}{l}23(20.1) \\
54(47.4) \\
37(32.5)\end{array}$ & $\begin{array}{l}28(24.6) \\
54(47.4) \\
32(28.0)\end{array}$ \\
\hline 4 & $\begin{array}{l}\text { Suffered any illness pregnant in the last } 3 \\
\text { months }\end{array}$ & $\begin{array}{l}\text { Yes } \\
\text { No }\end{array}$ & $\begin{array}{l}2(1.8) \\
112(98.2)\end{array}$ & $\begin{array}{l}2(1.8) \\
112(98.2)\end{array}$ \\
\hline 5 & Diarrhea illness in past two weeks & $\begin{array}{l}\text { Yes } \\
\text { No }\end{array}$ & $\begin{array}{l}3(2.6) \\
111(97.4)\end{array}$ & $\begin{array}{l}2(1.8) \\
112(98.2)\end{array}$ \\
\hline 6 & Fever in last two weeks & $\begin{array}{l}\text { Yes } \\
\text { No }\end{array}$ & $\begin{array}{l}12(10.5) \\
102(89.5)\end{array}$ & $\begin{array}{l}2(1.8) \\
112(98.2)\end{array}$ \\
\hline 7 & If yes, how many times a week & $\begin{array}{l}\text { >more than } \\
\text { a week } \\
\text { <less than a week }\end{array}$ & $\begin{array}{l}5(4.3) \\
7(6.1)\end{array}$ & $\begin{array}{l}\text { I (0.9) } \\
\text { I (0.9) }\end{array}$ \\
\hline
\end{tabular}

Table 4 Anthropometric Characteristics Pregnancy Mother Attending ANC in Selected Jigjiga Public Health Facilities, 2019

\begin{tabular}{|l|l|l|l|l|}
\hline $\mathbf{S} /$ & Variables & Categorical & $\begin{array}{l}\text { Case } \\
\text { (n=I I4) } \\
\text { Frequency } \\
(\%)\end{array}$ & $\begin{array}{l}\text { Control } \\
(\mathbf{n}=1 \text { I4) } \\
\text { Frequency } \\
(\%)\end{array}$ \\
\hline I & MUAC & $\begin{array}{l}<23 \mathrm{~cm} \\
>23 \mathrm{~cm}\end{array}$ & $\begin{array}{l}108(94.7) \\
6(5.3)\end{array}$ & $\begin{array}{l}79(69.3) \\
35(30.7)\end{array}$ \\
\hline
\end{tabular}

were 7.2 times more likely to develop anemia compared to those mothers who consumed it every day $[\mathrm{AOR}=7.245$; $95 \% \mathrm{CI}=(2.007-26.151)]$. The odds of developing anemia in pregnant mothers who did not ever consume red meat were 8.6 times higher than those mothers who consumed it every day $[\mathrm{AOR}=8.690 ; 95 \% \mathrm{CI}=(1.795-42.072)]$. Similarly, with green vegetables, the odds of developing anemia were 2.9 times higher in women who ate green vegetables $1-2$ times a week $[\mathrm{AOR}=2.970 ; 95 \% \mathrm{CI}=(1$.012-8.716)], 8 times higher in mothers who ate green vegetables $1-2$ times a month $[\mathrm{AOR}=8.057 ; 95 \% \mathrm{CI}=(2$.358-27.526)], compared to those who are them every day. Having a MUAC of less than $23 \mathrm{~cm}$ meant that mothers were 16 times more likely to acquire anemia $[\mathrm{AOR}=16.432 ; 95 \% \mathrm{CI}=(5.240-51.526)]$ as shown in Table 5.

\section{Discussion}

Anemia is a considerable public health problem worldwide. In developing countries such as Ethiopia, this becomes even more of a problem during pregnancy. Anemia has multiple causes, and the associated risk factors vary widely across populations and communities. The current study identified three predictors of anemia among pregnant women who were attending antenatal care in Jigjiga, Ethiopia.

One of the main objectives of the present study was to relate the presence of anemia with dietary intake during pregnancy. The odds of developing anemia were significantly higher in pregnant mothers who consumed red meat $1-2$ times a month $(\mathrm{AOR}=7.245)$, or not at all $(\mathrm{AOR}=8.7)$, in comparison to mothers who consumed it every day. This finding is in agreement with previous studies conducted in Pakistan and Sidama Zone, southern Ethiopia, which showed that pregnant mothers who did not eat red meat or organ meat were more likely to be anemic compared to pregnant women who did, because red meat is rich in iron that enhances the hemoglobin level, especially during pregnancy where iron demand is high. ${ }^{17-19}$ These studies may be in agreement because of similar choices by the study population to reduce or exclude red meat from the diet as a dietary preference, or due to low socioeconomic 
Table 5 Determinant of Anemia Among Pregnant Women Attending ANC in Selected Jigjiga Public Health Facilities, 2019

\begin{tabular}{|c|c|c|c|c|c|}
\hline Variables & Cases $n=1 \mid 4(\%)$ & Controls $n=114$ (\%) & COR $(95 \% \mathrm{Cl})$ & AOR (95\% Cl) & P-value \\
\hline \multicolumn{6}{|l|}{ Educational status } \\
\hline Informal & $97(85.1)$ & $71(62.3)$ & $3.456(1.823-6.55)$ & $1.34(0.56-3.19)$ & 0.498 \\
\hline Formal & $17(15.0)$ & $43(37.7)$ & 1 & & \\
\hline \multicolumn{6}{|l|}{ Monthly income } \\
\hline $500-5000(E T B / U S D=0.029)$ & 104 (9I.2) & $75(65.8)$ & $5.4 \mid(2.54-\mid 1.5 I)$ & $1.84(0.68-4.99)$ & 0.225 \\
\hline $5000-1000(E T B / U S D=0.029)$ & $10(8.8)$ & $39(34.2)$ & I & & \\
\hline \multicolumn{6}{|l|}{ Red meat } \\
\hline Everyday & $8(7.0)$ & $29(25.4)$ & 1 & 1 & 1 \\
\hline 3-5times a week & II (9.6) & $32(28.1)$ & $1.24(0.44-3.52)$ & $1.20(0.35-4.02)$ & 0.765 \\
\hline I-2 times a week & $25(21.9)$ & $35(30.7)$ & $2.58(1.05-6.60)$ & $2.09(0.64-6.77)$ & 0.219 \\
\hline $\mathrm{I}-2$ times a month & $37(32.5)$ & $14(12.3)$ & $9.58(3.54-25.92)$ & $7.24(2.00-26.15)$ & $0.002^{*}$ \\
\hline Do not take & $33(28.9)$ & $4(3.5)$ & $29.90(8.15-109.71)$ & $8.69(1.79-42.07)$ & $0.007^{*}$ \\
\hline \multicolumn{6}{|l|}{ Green vegetable } \\
\hline Everyday & $16(14.0)$ & $47(4 \mid .2)$ & 1 & 1 & 1 \\
\hline 3-5times a week & $15(13.2)$ & $36(31.6)$ & $1.22(0.53-2.80)$ & $0.91(0.35-2.34)$ & 0.847 \\
\hline I-2 times a week & $22(19.3)$ & $14(12.3)$ & $4.61(1.91-11.10)$ & $2.97(\mathrm{I} .0 \mathrm{I}-8.7 \mathrm{I})$ & $0.048^{*}$ \\
\hline I-2times a month & $39(34.2)$ & $10(8.8)$ & II .45 (4.67-28.09) & 8.05 (2.35-27.52) & $0.001 *$ \\
\hline Do not take & $22(19.3)$ & $7(6.1)$ & $9.23(3.32-25.66)$ & $3.15(0.86-11.55)$ & $0.083^{*}$ \\
\hline \multicolumn{6}{|l|}{ MUAC } \\
\hline$<23 \mathrm{~cm}$ & $108(94.7)$ & $79(69.3)$ & $7.97(3.19-19.87)$ & $16.4(5.24-5 \mid .52)$ & $0.000^{*}$ \\
\hline$>23 \mathrm{~cm}$ & $6(5.3)$ & $35(30.7)$ & 1 & 1 & I \\
\hline
\end{tabular}

Note: *Statistically significant.

Abbreviations: $\mathrm{AOR}$, adjusted odd ratio; $\mathrm{Cl}$, confidence interval; $\mathrm{COR}$, crude odd ratio.

status, since both the countries referred to are low-income countries where food availability and food security are low.

Another important finding in this study was that relating to green vegetables. The odds of being anemic were significantly higher among mothers who ate green vegetables $1-2$ times a week ( $\mathrm{AOR}=2.97$ times) more likely to become anemic compared to Their counterpart (every day), $[\mathrm{AOR}=2.970,95 \% \mathrm{CI}(1.012-8.716)]$ and the odds of being anemic among mothers who eat 1-2 times a month green vegetable were 8 times risk or 1-2 times a month $(\mathrm{AOR}=8.057)$, compared to mothers who ate green vegetables every day $[\mathrm{AOR}=8.057,95 \% \mathrm{CI}$ (2.358-27.526)]. This finding is consistent with a previous study conducted in Dessie, northern Ethiopia, which reported low consumption of green vegetables to be significantly associated with an increased risk of anemia. ${ }^{20}$ Consumption of leafy green vegetables increases hemoglobin concentration, and has the potential to minimize the risk of anemia. ${ }^{21}$ The correspondence between these findings could be due to poor dietary diversity across Ethiopia, which results in a dietary shortage of micronutrients, or due to the widespread inability to grow, source or afford green vegetables. In contrast, a study from the West Arsi Zone, Oromia Region, Ethiopia reported that the intake of green vegetables had no association with anemia. ${ }^{19}$ This disparity might be due to other factors that may act to reduce iron absorption and storage in the body.

Pregnant women with a MUAC of less than $23 \mathrm{~cm}$ were 16 times more likely to acquire anemia comparing to those who had MUAC greater than $23 \mathrm{~cm}[\mathrm{AOR}=16.432$, 95\% CI (5.240-51.526)]. MUAC is a measure widely used for the assessment of nutritional status, and $23 \mathrm{~cm}$ is the threshold circumference considered to determine the level of nourishment of an adult female, and circumferences less than this signifying undernourishment. This is in agreement with similar findings documented in eastern Ethiopia and west Ethiopia, Kenya, Nepal, and India. ${ }^{22-27}$ The similarity of these studies demonstrates beyond a doubt that undernourished pregnant women have a higher probability of developing anemia because pregnancy is widely understood to be the most nutritionally-demanding period in a women's life. ${ }^{28}$ The nutritional disadvantage of pregnancy may take its toll later in pregnancy, as women are 
not able to meet with the demand from the growing fetus, resulting in harm to the mother and ultimately loss of the fetus.

\section{Limitations of the Study}

This study was a facility-based study only incorporating two recruitment sites. It is therefore not easy to generalize to these data across different regions of the same country, or to other developing and developed nations. The possibility of inter-observer error during measurements is considered a constraint of this study, despite all data collection being supervised, and all personnel undergoing two days' training prior to commencing data collection.

\section{Conclusion}

This study demonstrated that women who did not get sufficient red meat or green vegetables in their diet, and those had a middle-upper arm circumference of less than $23 \mathrm{~cm}$ were significantly more likely to develop anemia during pregnancy. Based on these findings, it is recommended that special attention be paid for anemia prevention strategies, through the preparation of a program to improve the nutritional status of pregnant women, specifically aimed at those with low nutritional status. Programs should include nutritional counseling on ironrich foods and increasing nutritional diversity. Pregnant women in developing countries should be encouraged to enroll in such programs in order to prevent negative birth outcomes through improved iron intake and the provision of a varied diet. Following this, a community-based study with a large sample size and longitudinal study design should be conducted to assess the efficacy of interventions and monitor the impact of local and nationwide programs.

\section{Abbreviations}

DDQ, Dietary diversity Questionnaire; EDHS, Ethiopian Demographic Health Survey; IDA, iron deficiency anemia; MUAC, mid-upper arm circumference; RBC, red blood cells; SPSS, Statistical package for Social Sciences; WHO, World Health Organization.

\section{Acknowledgments}

We would like to extend our acknowledgment of selected public health facilities in Jigjiga for providing the approval to conduct the study. We would also like to express our gratitude to the data collectors for their cooperation and hard work.

\section{Disclosure}

The authors report no conflicts of interest in this work.

\section{References}

1. Organization WH. Global Nutrition Targets 2025: Policy Brief Series. World Health Organization; 2014.

2. Anaemia ID, Assessment PJWHOG. Control: A Guide for Programme Managers. Switzerland; 2001.

3. Salhan S, Tripathi V, Singh R, Gaikwad HSJA. Evaluation of hematological parameters in partial exchange and packed cell transfusion in treatment of severe anemia in pregnancy. Anemia. 2012;2012.

4. Organization WH. Neonatal and Perinatal Mortality: Country, Regional and Global Estimates; 2006.

5. Gedefaw L, Ayele A, Asres Y, Mossie A. Anaemia and associated factors among pregnant women attending antenatal care clinic in Walayita Sodo town, Southern Ethiopia. Ethiop J Health Sci. 2015;25(2):155-164. doi:10.4314/ejhs.v25i2.8

6. Pathirana J, Munoz FM, Abbing-Karahagopian V, et al. Neonatal death: case definition \& guidelines for data collection, analysis, and presentation of immunization safety data. Vaccine. 2016;34(49):6027-6037.

7. Kefiyalew F, Zemene E, Asres Y, Gedefaw L. Anemia among pregnant women in Southeast Ethiopia: prevalence, severity and associated risk factors. BMC Res Notes. 2014;7(1):771.

8. Black RE, Victora CG, Walker SP, et al. Maternal and child undernutrition and overweight in low-income and middle-income countries. Lancet. 2013;382(9890):427-451.

9. EDHS E. Demographic and health survey 2016: key indicators report. DHS Program ICF. 2016;363:364.

10. Kassa GM, Muche AA, Berhe AK, Fekadu G. Prevalence and determinants of anemia among pregnant women in Ethiopia; a systematic review and meta-analysis. BMC Hematol. 2017;17(1):17.

11. Bizuneh Ayano BA. Assessment of prevalence and risk factors for anemia among pregnant mothers attending ANC clinic at Adama Hospital Medical Collage, Adama, Ethiopia. Am J Gynecol Obstet. 2017;6:31-39. doi:10.11648/j.jgo.20180603.11

12. CSA. Population and Housing Census of Ethiopia. In: Agency CS, ed. Addis Ababa; 2015.

13. Weldekidan F, Kote M, Girma M, Boti N, Gultie T. Determinants of anemia among pregnant women attending antenatal clinic in public health facilities at Durame Town: unmatched case control study. Anemia. 2018;2018.

14. Ververs M-T, Antierens A, Sackl A, Staderini N, Captier V. Which anthropometric indicators identify a pregnant woman as acutely malnourished and predict adverse birth outcomes in the humanitarian context? PLOS Curr. 2013;5.

15. Bendel RB, Afifi A. Comparison of stopping rules in forward "stepwise" regression. J Am Stat Assoc. 1977;72(357):46-53.

16. Mickey RM, Greenland S. The impact of confounder selection criteria on effect estimation. Am J Epidemiol. 1989;129(1):125-137.

17. Argaw B, Argaw-Denboba A, Taye B, Worku A, Worku A. Major risk factors predicting anemia development during pregnancy: unmatched-case control study. J Community Med Health Educ. 2015;5(353):2161-0711.1000353.

18. Baig-Ansari N, Badruddin SH, Karmaliani R, et al. Anemia prevalence and risk factors in pregnant women in an urban area of Pakistan. Food Nutr Bull. 2008;29(2):132-139.

19. Obse N, Mossie A, Gobena T. Magnitude of anemia and associated risk factors among pregnant women attending antenatal care in Shalla Woreda, West Arsi Zone, Oromia Region, Ethiopia. Ethiop J Health Sci. 2013;23(2):165-173.

20. Tadesse SE, Seid O, Mariam Y, et al. Determinants of anemia among pregnant mothers attending antenatal care in Dessie town health facilities, northern central Ethiopia, unmatched case-control study. PloS One. 2017;12(3):e0173173. 
21. Egbi G, Gbogbo S, Mensah GE, Glover-Amengor M, Steiner-Asiedu MJBN. Effect of green leafy vegetables powder on anaemia and vitamin-A status of Ghanaian school children. BMC Nutr. 2018;4 (1):27.

22. Addis Alene K, Mohamed Dohe A. Prevalence of anemia and associated factors among pregnant women in an urban area of Eastern Ethiopia. Anemia. 2014;2014.

23. Bereka S, Gudeta A, Reta M, Ayana LA. Prevalence and associated risk factors of anemia among pregnant women in rural part of JigJiga City, Eastern Ethiopia: a cross sectional study. J Preg Child Health. 2017;4(337):2.

24. Tulu BD, Atomssa EM, Mengist H. Determinants of anemia among pregnant women attending antenatal care in Horo Guduru Wollega Zone, West Ethiopia: unmatched case-control study. PloS One. 2019;14(10):e0224514.

25. Okube OT, Mirie W, Odhiambo E, Sabina W, Habtu M. Prevalence and factors associated with anaemia among pregnant women attending antenatal clinic in the second and third trimesters at Pumwani maternity hospital, Kenya. J Obstet Gynecol. 2016;6(1):16-27.
26. Makhoul Z, Taren D, Duncan B, et al. Risk factors associated with anemia, iron deficiency and iron deficiency anemia in rural Nepali pregnant women. Southeast Asian J Trop Med Public Health. 2012;43(3):735.

27. Mondal B, Tripathy V, Gupta RJJHE. Risk factors of anemia during pregnancy among the Garo of Meghalaya, India. J Hum Ecol. 2006;14:27-32.

28. Gebremedhin S, Enquselassie F. Correlates of anemia among women of reproductive age in Ethiopia: evidence from Ethiopian DHS 2005. Ethiop J Health Dev. 2011;25(1):22-30. doi:10.4314/ejhd.v25i1. 69842
Journal of Multidisciplinary Healthcare

\section{Publish your work in this journal}

The Journal of Multidisciplinary Healthcare is an international, peerreviewed open-access journal that aims to represent and publish research in healthcare areas delivered by practitioners of different disciplines. This includes studies and reviews conducted by multidisciplinary teams as well as research which evaluates the results or conduct of such teams or healthcare processes in general. The journal

\section{Dovepress}

covers a very wide range of areas and welcomes submissions from practitioners at all levels, from all over the world. The manuscript management system is completely online and includes a very quick and fair peer-review system. Visit http://www.dovepress.com/testimonials. php to read real quotes from published authors. 